\title{
Ikke «bare» svangerskapskvalme
}

Kvalme og oppkast i svangerskapet rammer opptil $80 \%$ av alle gravide, men er oftest selvbegrensende og uten komplikasjoner. Hyperemesis gravidarum er den mest uttalte form for svangerskapskvalme og rammer ca. $1 \%$ (1). Ved denne tilstanden er sykehusbehandling nødvendig for å korrigere væske- og elektrolyttstatus samt gjenopprette ernæringsstatus. Det er imidlertid viktig å understreke at hyperemesis gravidarum er en eksklusjonsdiagnose. Kasuistikken til Hatle og medarbeidere er et eksempel på dette. Forfatterne beskriver en pasient med oesophagusakalasi, der tilstanden initialt ble oppfattet som hyperemesis.

Andre gastrointestinale tilstander som er vanligere årsaker til kvalme i svangerskapet er gastroenteritt og appendisitt. Man må også vurdere flere differensialdiagnoser urogenitale (cystitt og pyelonefritt), nevrologiske (migrene og hjernesvulst) og endokrinologiske (tyreotoksikose og Addisons sykdom).

Ingen spesifikk diagnostisk test påviser hyperemesis gravidarum. Det er vist at spørreskjemaet PUQE (Pregnancy Unique Questionnaire of Emesis) skiller alvorlig fra mindre alvorlig grad av svangerskapskvalme (2). Skjemaet valideres nå på norsk (3) for bedre å kunne identifisere dem som trenger sykehusbehandling.

Anamnesen kan være til hjelp i diagnostikken: Hyperemesis oppstår i svangerskap. Hvis kvalme, oppkast eller vekttap foreligger før graviditeten, bør man, som hos den aktuelle pasienten, definitivt utelukke andre årsaker.

Å skille hyperemesis fra andre tilstander med utspring i øvre gastrointestinaltractus kan være vanskelig. Hvis hyperemesispasienter trenger ernæring utover det man kan oppnå ved å gi perifert intravenøst ernæringstilskudd, er sondeernæring et godt alternativ (4). Ved å legge sonden ned ved gastroskopi vil man få inspisert oesophagus, ventrikkel og duodenum, og patologiske forhold i disse tarmavsnitt vil kunne bli avdek- ket. Vanligvis får man god oversikt, og sonden kan uten problemer legges ned. Når det, som hos den aktuelle pasient, påvises betydelige mengder retinerte matrester, noe som gir dårlig oversikt, vil det i seg selv gi indikasjon på at det foreligger spesifikk gastrointestinal sykdom og ikke «bare» svangerskapskvalme.

Hatle og medarbeideres kasuistikk illustrerer også et annet viktig poeng: Hvis ernæringen er utilstrekkelig, er det økt risiko for svangerskapskomplikasjoner. Under $7 \mathrm{~kg}$ total vektøkning i svangerskapet hos kvinner med hyperemesis gravidarum er assosiert med fødsel før termin og vekstretardasjon hos barnet (5).

Det er sannsynlig at tiltak for å gjenopprette positiv energibalanse er nyttig og viktig. Man kan gi totalt $1-1,51$ parenteral næringsløsning per døgn i perifer venekanyle. Dette tilsvarer vel $1000 \mathrm{kcal}$ eller halvparten av det totale energibehovet, mens $5 \%$ glukoseoppløsning kun gir $200 \mathrm{kcal} / \mathrm{l}$. Skal hele energibehovet dekkes (total parenteral ernæring), må man benytte sentralvenøst kateter. Det gir risiko for pneumothorax, sepsis og trombose.

Et bedre alternativ, uten risiko for slike komplikasjoner, er ernæringsløsning gitt via nasoenteral ernæringssonde. Dette kan man fortsette med også etter utskrivning. Normalt vil ernæringsbehovet dekkes med 21 sondeløsning per døgn. I Norge har sondeernæring vært benyttet ved hyperemesis gravidarum siden 1993 (4), og dette anbefales nå som førstevalg ved behov for langvarig ernæring også hos gravide $(1,6)$.

Hatle og medarbeidere beskriver sondeernæring helt frem til forløsningen. Det var vanskelig å gi mer enn 1,5 1 sondeløsning i døgnet. Deres pasient fikk ingen vektøkning og barnet var undervektig, men sprekt ved fødselen. Det er mulig å gi mer optimalisert ernæring med energi- og/eller proteinforsterket sondeløsning hvis man ikke når det anbefalte døgnvolum.

Veiing er den enkleste måten å kontrollere effekten av næringsinntaket på, også i svangerskap. Både ved hyperemesis gravidarum og ved andre tilstander med underernæring bør man tilstrebe å oppnå (og dokumentere) at behandlingen gir adekvat vektøkning. Mange sykehus har kliniske ernæringsfysiologer som vil kunne hjelpe med å lage individuelt tilpassede ernæringsplaner når standard ernæringsregime ikke er tilstrekkelig for å nå målet.

\section{Jone Trovik}

jone.trovik@helse-bergen.no

Kvinneklinikken

Haukeland universitetssykehus

Jone Trovik (f. 1961) er spesialist i fødselshjelp og kvinnesykdommer og har en ph.d.-grad.

Hun er leder av Norsk Gynekologisk Forening.

Forfatter har fylt ut ICMJE-skjemaet og oppgir ingen interessekonflikter.

\section{Litteratur}

1. Niebyl JR. Clinical practice. Nausea and vomiting in pregnancy. N Engl J Med 2010; 363: 1544-50.

2. Koren G. Piwko C, Ahn E et al. Validation studies of the Pregnancy Unique-Quantification of Emesis (PUQE) scores. J Obstet Gynaecol 2005; 25: 241-4.

3. ClinicalTrials.gov. Pregnancy Specific Nausea Questionnaire (PUQE) Translated and Tested in Norwegian (PUQE-N). http://clinicaltrials.gov/ct2/ show/NCT01836835 (4.11.2013)

4. Trovik J, Haram K, Berstad A et al. Nasoenteral sondeernæring ved hyperemesis gravidarum. Et alternativ til parenteral ernæring. Tidsskr Nor Lægeforen 1996; 116: 2442-4.

5. Dodds L, Fell DB, Joseph KS et al. Outcomes of pregnancies complicated by hyperemesis gravidarum. Obstet Gynecol 2006; 107: 285-92.

6. American College of Obstetrics and Gynecology. ACOG (American College of Obstetrics and Gynecology) Practice Bulletin: nausea and vomiting of pregnancy. Obstet Gynecol 2004; 103: 803-14.

Mottatt 11.10. 2013, første revisjon innsendt 4.11. 2013, godkjent 13.11. 2013. Redaktør: Sigurd Høye. 